\title{
Physical map of the chromosome of the phytopathogenic bacterium Pseudomonas syringae pv. phaseolicola
}

\author{
M. Esther De Ita, Rodolfo Marsch-Moreno, Plinio Guzmán \\ and Ariel Alvarez-Morales
}

Author for correspondence: Ariel Alvarez-Morales. Tel: +52 462396 00. Fax: +5246245846. e-mail: aalvarez@irapuato.ira.cinvestav.mx

CINVESTAV, IPN, Unidad Irapuato, Department of Plant Genetic Engineering, Apdo. Postal 629, Irapuato, GTO 36500, Mexico

\begin{abstract}
Pseudomonas syringae pv. phaseolicola (P.s. phaseolicola) is one of about 45 recognized pathovars within the $P$. syringae group and is the causal agent of halo-blight disease of beans. DNA from this bacterium digested to completion with two different restriction enzymes, Pacl and Pmel, yielded 15 and 16 fragments, respectively. These were separated using PFGE and sized by comparison to known molecular mass markers. The P.S. phaseolicola chromosome was determined to be approximately 5.64 Mb in size. To link the different fragments obtained into a circular chromosome map for both enzymes, 150 random Tn5 mutants of P.s. phaseolicola were used as a source of DNA and the identification of the band carrying the transposon 'tag' in each mutant was done after PFGE and Southern hybridization of a complete chromosomal digestion using a Tn5 probe. Partial digestions of DNA from different Tn5 mutants 'tagging' specific bands were then generated and the complete and partial products of the digestion separated by PFGE and identified with a Tn5 probe. By calculating the size of the partial products, it was then possible to link different bands into a physical map. This is the first report on the construction of a physical map of a member of the $P$. syringae group and should be invaluable for molecular genetic analysis in this species and in evolutionary or taxonomic studies when compared to similar data obtained for any of the other recognized pathovars.
\end{abstract}

Keywords: chromosome size, physical map, Pseudomonas syringae pv. phaseolicola, pulsed-field gel electrophoresis, transposons

\section{INTRODUCTION}

Research on plant-pathogenic bacteria at the molecular level is being carried out in many academic and industrial laboratories throughout the world because of the need for a better understanding of the basic principles that govern bacteria-plant interactions if new and lasting strategies of control are to be found. Pseudomonas syringae is a large group of phytopathogenic bacteria comprising 45 different pathovars which cause disease on a wide range of plant hosts (Young et al., 1992). Of these, P. syringae pv. phaseolicola (P.s. phaseolicola) is the causal agent of 'Halo blight' disease of beans (Phaseolus vulgaris L.) which affects large extensions of rain-fed fields throughout Mexico and Central and South America.

P.s. phaseolicola produces a toxin known as phaseolotoxin which is synthesized at $16-18^{\circ} \mathrm{C}$ (Goss, 1970), together with a phaseolotoxin-resistant ornithine carbamoyltransferase, the product of the $\operatorname{argK}$ gene, which confers immunity to this bacterium against its own toxin (Mitchell, 1978; Peet \& Panopoulos, 1987) and which has been cloned and characterized (Mosqueda $e t$ al., 1990; Hatziloukas \& Panopoulos, 1992). In our laboratory we are using P.s. phaseolicola as a model system to study the molecular mechanisms involved in the pathogenic interaction with its host plant. We are also interested in studying genome organization and evolution within the $P$. syringae group which still lacks well-developed molecular genetics and, to date, no comprehensive genetic or physical map for any member of this group is available. As a first step toward the analysis of genome organization and as a tool for genetic and evolutionary analysis we decided to construct a physical map of P.s. phaseolicola.

The availability of techniques such as PFGE provides the 
means to separate and accurately measure the size of large DNA fragments or even whole chromosomes (Schwartz \& Cantor, 1984; Smith et al., 1987a ; Snell \& Wilkins, 1986; Sor, 1988). This technique combined with the use of restriction enzymes that cleave infrequently within the bacterial chromosome has been applied to estimate the sizes of circular chromosomes of several different bacteria (Smith et al., 1987b; Pyle et al., 1988; Lee \& Smith, 1988; Kauc et al., 1989; Lee et al., 1989; Manna \& Das, 1993, 1994) including those of four different strains of $P$. aeruginosa (Römling et al., 1989; Hector \& Johnson, 1990) and P. fluorescens (Rainey \& Bailey, 1996). We estimated the size of the P.s. phaseolicola chromosome to be $5.64 \mathrm{Mb}(5.641 \pm 0.13)$ and that it is a single circular chromosome yielding 15 and $16 \mathrm{PacI}$ and PmeI restriction fragments, respectively.

To establish the relative position of the different fragments obtained with each restriction enzyme, 'tagging' each individual fragment was used as an alternative to double restrictions and two-dimensional PFGE. To this end, total DNA from $150 \mathrm{Tn} 5$ mutants of P.s. phaseolicola was obtained and by using PacI and PmeI, PFGE and Southern blotting with a Tn5-specific probe, it was possible to readily identify the specific $\mathrm{PacI}$ or PmeI band carrying a transposon 'tag' and construct a physical map of the genome. Also, we have found some mutants in which promoter activity is dependent on temperature or the presence of plant extracts. The corresponding mutations together with the $\operatorname{argK}$ gene and five transcriptional units for rRNA have been located on the physical map obtained in this work.

\section{METHODS}

Bacterial strain and culture conditions. P.s. phaseolicola strain Riverside was kindly provided by Dr Noel T. Keen (University of California, Riverside) and was routinely grown in Kings medium B (KB; Lelliott \& Stead, 1987) at $28^{\circ} \mathrm{C}$.

Preparation of chromosomal DNA. Chromosomal DNA of P.s. phaseolicola was prepared according to Smith et al. (1988) with some modifications. The cells were grown at $28^{\circ} \mathrm{C}$ overnight on a rotary shaker in $5 \mathrm{ml} \mathrm{KB}$. From this culture $1 \mathrm{ml}$ was inoculated into $50 \mathrm{ml}$ fresh $\mathrm{KB}$ in a $250 \mathrm{ml}$ Erlenmeyer flask. The culture was grown at $28^{\circ} \mathrm{C}$ and shaken (250 r.p.m.) until the density of the culture reached 70 Klett units (using a red filter). The cells were chilled to $4{ }^{\circ} \mathrm{C}$, harvested by centrifugation at $5000 \mathrm{~g}$ for $15 \mathrm{~min}$ and washed in $50 \mathrm{ml}$ Pett IV buffer $(0 \cdot 01 \mathrm{M}$ Tris $/ \mathrm{HCl}, \mathrm{pH} 7 \cdot 6,1 \mathrm{M} \mathrm{NaCl})$ followed by centrifugation at $5000 \mathrm{~g}$ for $10 \mathrm{~min}$. The cells were finally resuspended in $8 \mathrm{ml}$ Pett IV at $4{ }^{\circ} \mathrm{C}$. The suspension was warmed to room temperature for $15 \mathrm{~min}$ and mixed with an equal volume of $1.2 \%(\mathrm{w} / \mathrm{v})$ low-melting-temperature agarose (Sea Plaque GTG agarose; FMC) made up in sterile water at $42^{\circ} \mathrm{C}$. The resulting suspension was poured into a mould chamber (Bio-Rad). Solidified blocks were immersed in EC lysis solution $(6 \mathrm{mM}$ Tris/ $\mathrm{HCl}, \mathrm{pH} 7 \cdot 6,1 \mathrm{M} \mathrm{NaCl}$, $100 \mathrm{mM}$ EDTA, pH 7.6, 0.5\% Brij $58,0.2 \%$ sodium deoxycholate, $0.5 \%$ sodium lauryl sarcosine, $1 \mathrm{mg}$ lysozyme $\mathrm{ml}^{-1}$, $10 \mathrm{mg}$ DNase-free RNase $\mathrm{ml}^{-1}$ ) and incubated at $37^{\circ} \mathrm{C}$ for $18 \mathrm{~h}$. The solution was changed to ESP $(0.5 \mathrm{M}$ EDTA, pH 8.0, $1 \%$ sodium lauryl sarcosine, $1 \mathrm{mg}$ proteinase $\mathrm{K} \mathrm{ml}^{-1}$ ) and incubated for $48 \mathrm{~h}$ at $50^{\circ} \mathrm{C}$. Proteinase activity was inhibited by washing the blocks three times for $1 \mathrm{~h}$ at $50^{\circ} \mathrm{C}$ in $40 \mathrm{mg}$ PMSF $\mathrm{ml}^{-1}$. The blocks were then stored in $0.05 \mathrm{M}$ EDTA, $\mathrm{pH} 8.0$, at $4{ }^{\circ} \mathrm{C}$.

Digestion of chromosomal DNA with restriction endonucleases. Agarose blocks containing P.s. phaseolicola chromosomal DNA were subjected to single digestions with restriction endonucleases. Each agarose block was washed three times in 50 vols TE buffer $(10 \mathrm{mM}$ Tris $/ \mathrm{HCl}, \mathrm{pH} 7 \cdot 6$, $1 \mathrm{mM}$ EDTA) prior to digestion and then equilibrated with the corresponding digestion buffer at $4^{\circ} \mathrm{C}$ for $30 \mathrm{~min}$. DNA was digested with PacI or P meI at $37^{\circ} \mathrm{C}$ for $16-20 \mathrm{~h}$ in $0.25 \mathrm{ml}$ of the restriction buffer recommended by the manufacturer. For total digestion of DNA, $20 \mathrm{U}$ restriction endonuclease was used for each agarose block. When using I-CeuI, 1.3 U of enzyme was used, incubating the blocks at $37^{\circ} \mathrm{C}$ for $3 \mathrm{~h}$. The digestions were terminated by the addition of $100 \mathrm{mM}$ EDTA, pH 8.0. To partially digest DNA with PacI or PmeI, the reactions were performed as described above but allowing the digestion to proceed for only $5 \mathrm{~h}$. Alternatively, $4 \mathrm{U}$ restriction endonuclease was used for each agarose block at $37^{\circ} \mathrm{C}$ for $16-20 \mathrm{~h}$.

PFGE. PFGE was performed in $1.2 \%$ agarose (electrophoresis grade, Ultra Pure, Gibco-BRL) in $0.5 \times$ TBE buffer $(0.5 \times$ TBE buffer is $0.045 \mathrm{M}$ Tris/borate, $1 \mathrm{mM}$ EDTA, $\mathrm{pH} 8.0)$. The electrophoresis was regularly run at $14^{\circ} \mathrm{C}$ in a CHEF DR III apparatus from Bio-Rad using a linear increase in the pulse intervals. To resolve the shorter fragments pulse times were ramped from 8 to $24 \mathrm{~s}$ for $48 \mathrm{~h}$ at $165 \mathrm{~V}$. For separation of fragment sizes between 150 and $550 \mathrm{~kb}$ the gel was run for $48 \mathrm{~h}$ at $150 \mathrm{~V}$ with a pulse time from 15 to $60 \mathrm{~s}$. High molecular mass fragments $(>600 \mathrm{~kb})$ were resolved using $60-120 \mathrm{~s}$ ramped pulse times for $48 \mathrm{~h}$ at $150 \mathrm{~V}$. A $\lambda$ DNA ladder (monomer $48.5 \mathrm{~kb}$ ) from New England Biolabs was used for size marking. However, DNA fragments greater than $582 \mathrm{~kb}$ were resolved and sized by comparison with the Saccharomyces cerevisiae YPH80 chromosomes from Bio-Rad (size range $225-1900 \mathrm{~kb}$ ). Following electrophoresis, gels were stained with ethidium bromide $\left(1 \mathrm{mg} \mathrm{ml}^{-1}\right)$ for $30 \mathrm{~min}$, then destained in distilled water. The DNA bands were visualized with a UV transilluminator.

PFGE of large fragments generated with I-Ceul was carried out under different conditions to resolve the small or large fragments. For the three smaller fragments PFGE was performed in $1.2 \%$ agarose in $0.5 \times \mathrm{TBE}$ buffer using $60-120 \mathrm{~s}$ ramped pulse times for $66 \mathrm{~h}$ at $150 \mathrm{~V}$. Resolution of the five fragments obtained, including the largest two, was achieved by using $0.8 \%$ agarose in $0.5 \times \mathrm{TBE}, 500 \mathrm{~s}$ pulse, and allowing the separation to proceed for $68 \mathrm{~h}$ at $150 \mathrm{~V}$. The smaller fragments were sized against the $\lambda$ DNA ladder and the $S$. cerevisiae YPH 80 chromosomes. The larger fragments were sized against the chromosomes of the yeast Hansenula wingei (1.03-3.30 Mb range) purchased from BRL (Mega Base IV DNA Standard).

Southern blots and probe labelling. From a previously obtained collection of Tn5 mutants of P.s. phaseolicola (R. Marsch-Moreno, G. Hernández-Guzmán \& A. AlvarezMorales, unpublished), 150 strains were chosen at random and used to prepare and digest their chromosomal DNA as mentioned above. After PFGE, the DNA was depurinated and transferred to a Hybond-N membrane (Amersham) following standard techniques (Sambrook et al., 1989). Plasmid pUI244, a pBR322 derivative containing Tn5 (R. Marsch-Moreno and others, unpublished), was radioactively labelled with $\left[{ }^{32} \mathrm{P}\right] \mathrm{dCTP}$ (New England Nuclear) by random priming using 
commercial kits (Gibco-BRL; Random Primers DNA Labelling System). Hybridization was done at $65^{\circ} \mathrm{C}$ overnight, washed once with $0.1 \%$ SDS, $0.05 \%$ SSC (SSC is $0.15 \mathrm{M}$ sodium chloride, $0.015 \mathrm{M}$ sodium citrate) at room temperature and twice with $0 \cdot 1 \%$ SDS and $0 \cdot 1 \%$ SSC at $65^{\circ} \mathrm{C}$.

PCR-derived probes. Tn5 insertions could not be found in fragments A-E of the PmeI restriction products. Therefore, to generate $\mathrm{A}$-specific probes to identify partial digestion products, the A band was isolated from a preparative gel of chromosomal DNA from wild-type P.s. phaseolicola and used as template in a PCR reaction. These gels, from which the low molecular mass bands were going to be isolated, also allowed us to confirm that there were no smaller bands than those already identified in the PFGE gels. The agarose pieces containing the appropriate band to be used as template were melted in a boiling-water bath and diluted with an equal amount of distilled water. Three tenfold dilutions were obtained from this solution and stored at $4{ }^{\circ} \mathrm{C}$. PCR reactions were performed in an overall reaction volume of $50 \mu \mathrm{l}$ using $10 \mu \mathrm{l}$ of the $10^{-2}$ and $10^{-3}$ dilutions of template DNA, $5 \mu \mathrm{l}$ of a random 10 base oligonucleotide as primer and $35 \mu \mathrm{l}$ of a commercially premixed PCR solution (Gibco-BRL; PCR SuperMix). The PCR reaction was performed using an initial cycle of $94^{\circ} \mathrm{C}$ for $2 \mathrm{~min}$, then 40 cycles of $94^{\circ} \mathrm{C}$ for $1 \mathrm{~min}$, $37^{\circ} \mathrm{C}$ for $2 \mathrm{~min}$ and $72^{\circ} \mathrm{C}$ for $2 \mathrm{~min}$, followed by a final cycle of $72{ }^{\circ} \mathrm{C}$ for $7 \mathrm{~min}$. When specific fragments were amplified, these were eluted from an agarose gel, labelled with ${ }^{32} \mathrm{P}$ and used as probes to specifically identify complete and partial PmeI digestion products of P.s. phaseolicola.

\section{RESULTS}

\section{Selection of suitable enzymes for PFGE analysis of P.s. phaseolicola}

Long-range restriction mapping of bacterial genomes requires restriction endonucleases that cut only rarely on the chromosome. Criteria for the selection of appropriate enzymes are $\mathrm{G}+\mathrm{C}$ content, oligonucleotide frequency and the degree of methylation of the organism to be mapped. Pseudomonas has a G $+\mathrm{C}$ content of $67 \%$ and the tetranucleotide CTAG occurs more than an order of magnitude less frequently than calculated from mononucleotide frequencies (McClelland et al., 1987). Therefore, any restriction enzyme containing only A, T or A, T plus CTAG in its recognition sequence is a promising candidate for an appropriate rare-cutter. Several restriction endonucleases were chosen to be tested for the digestion of total DNA from P.s. phaseolicola. Of these, the enzymes PacI ( $5^{\prime}$ TTAATTAA) and PmeI (5' GTTTAAAC) contain only or predominantly $\mathrm{A}+\mathrm{T}$ base pairs in their recognition sequences, and SpeI $\left(5^{\prime}\right.$ ACTAGT) and XbaI (5' TCTAGA) contain the tetranucleotide CTAG within their recognition sequences. $\mathrm{Xbal}$ generated more than 40 bands of less than $50 \mathrm{~kb}$ and few fragments of around $150-250 \mathrm{~kb}$. Treatment with SpeI generated around 30 fragments, few of them ranging between $150-250 \mathrm{~kb}$ but the majority of the fragments being smaller (data not shown). PacI and PmeI digestion produced 15 and 16 fragments, respectively, ranging in size from 25 to $900 \mathrm{~kb}$. These fragments were efficiently separated by one-dimensional PFGE using a linear increase in the pulsed intervals with the appropriate conditions for resolving each restriction fragment. When undigested P.s. phaseolicola DNA was subjected to PFGE at short and long pulse times, three bands were usually clearly resolved in these gels. These bands did not correspond to any of the PacI- or PmeIgenerated fragments which strongly suggests that such bands are plasmids present in our particular strain (data not shown).

\section{Size of the P.s phaseolicola chromosome}

The molecular size of PFGE-separated fragments for both PacI and Pmel was determined by obtaining computer images of ethidium bromide-stained PFGE gels and using appropriate software to measure distances of band migration compared with both a $\lambda$ DNA ladder and S. cerevisiae YPH80 chromosome markers (Fig. 1). The data were analysed by linear regression. The size of the chromosome was determined by taking the sum of the sizes of individual restriction fragments obtained with PacI and PmeI enzymes from at least three independent gels. The chromosome size was determined to be $5 \cdot 641 \pm 0 \cdot 13 \mathrm{Mb}$ or $5 \cdot 64 \mathrm{Mb}$ (Table 1 ).

\section{Southern hybridization analysis of a collection of Tn5 mutants after complete and partial digestion of genomic DNA with Pacl and Pmel}

Total DNA from each of the Tn5 insertion mutants was subjected to complete digestion with both $\mathrm{PacI}$ and PmeI. After PFGE the DNA was transferred to a membrane and probed with a radioactively labelled plasmid containing Tn5. It was then possible to identify within the bands of the PacI or PmeI patterns where the transposon had inserted. Furthermore, hybridization also indicated the corresponding bands of both digestion patterns (Fig. 2a). As expected, Tn5 insertions were found more often in the larger fragments and few or none in the smaller ones. A list of representative Tn5 insertions is shown in Table 2.

The use of non-specific primers and PCR to generate hybridization probes for large restriction fragments has been reported (Poddar \& McClelland, 1992). Therefore, in those instances where a Tn5 tag could not be found for some of the bands obtained with either restriction enzyme, specific probes were obtained by PCR using DNA isolated from a preparative gel and random primers ( 10 bases) as a template or by directly using the gel-isolated DNA as probe after labelling with ${ }^{32} \mathrm{P}$. This information allowed us to determine the relative order of each fragment within the circular chromosome of P.s. phaseolicola. Such was the case for bands A-E of the PmeI digestion pattern. Therefore, bands $\mathrm{B}$ and $\mathrm{E}$ were isolated from a preparative gel, labelled with ${ }^{32} \mathrm{P}$ and used to probe a filter containing PacI and PmeI digestions of wild-type P.s. phaseolicola. As expected, this probe specifically identified band $\mathrm{E}$ of the PmeI digestion, but it also specifically identified bands 8 and 9 of the $\mathrm{PaCl}$ pattern, showing that these two bands were linked. This method allowed the unambiguous identification of bands in a complete digestion. However, due to small 
(a)

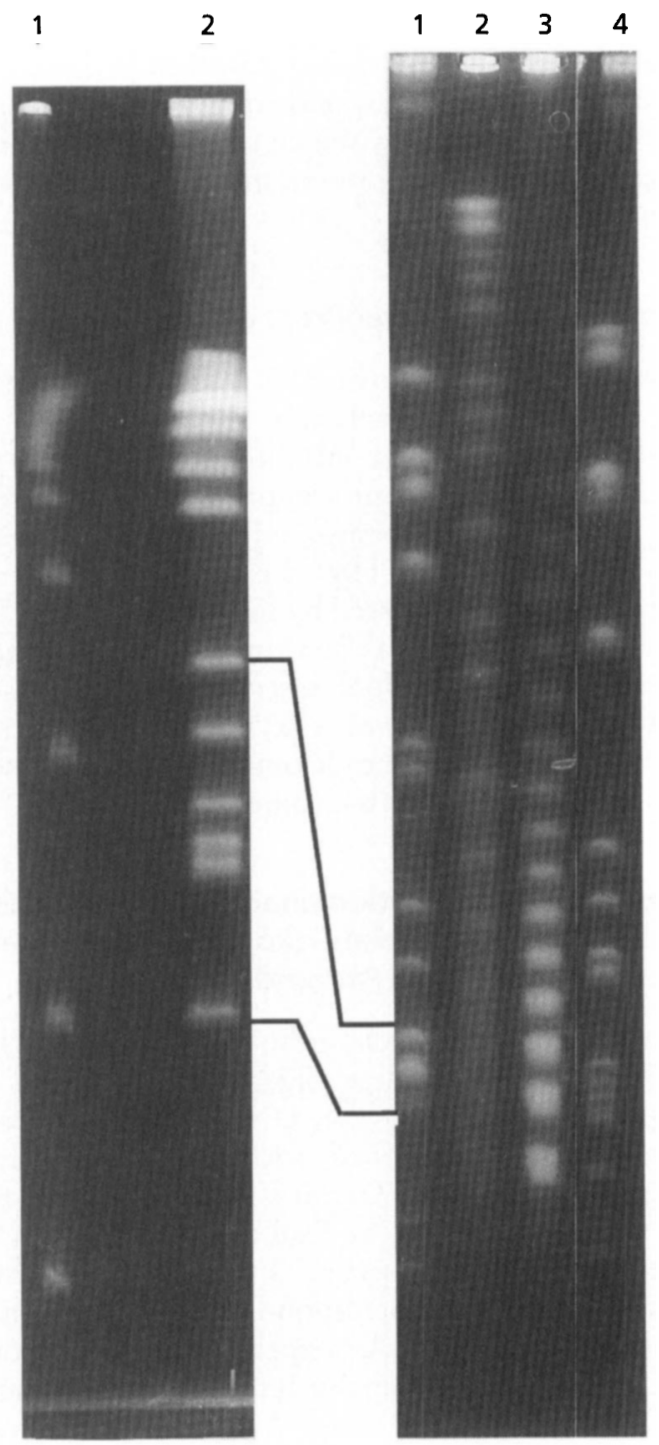

(c)

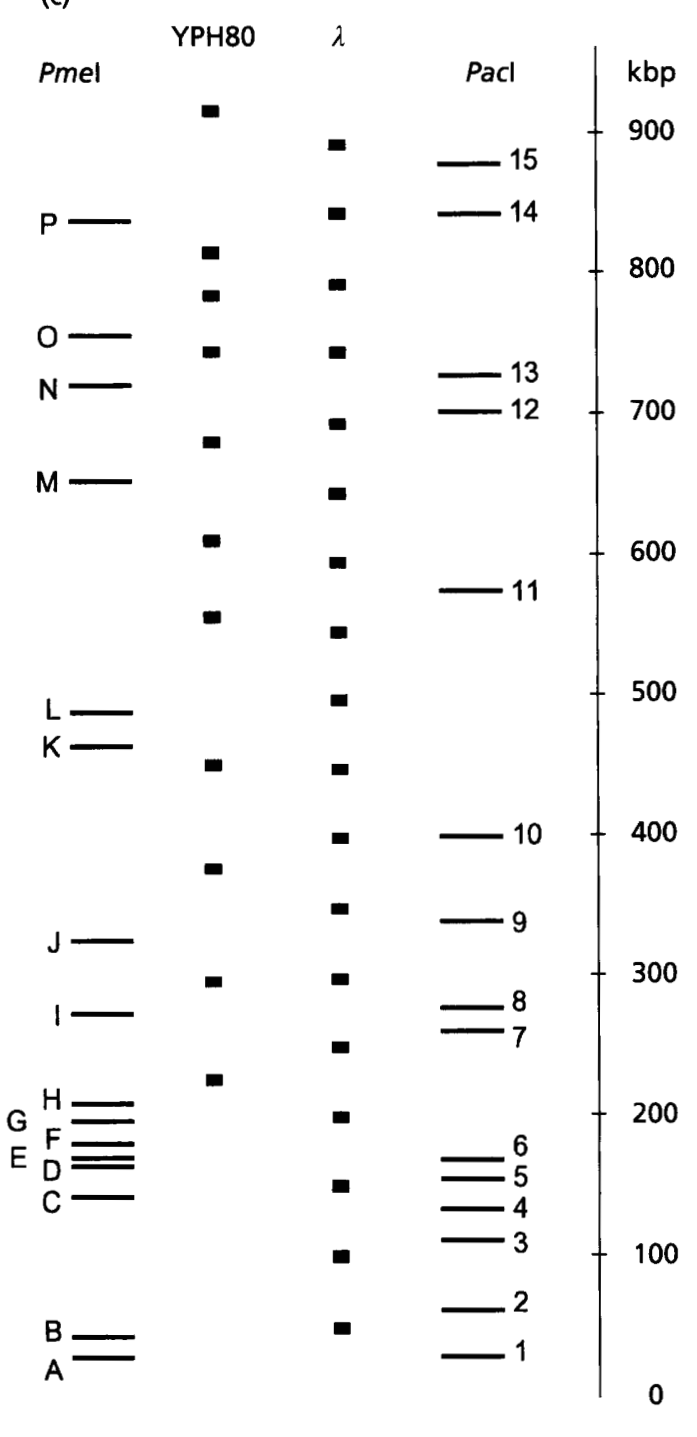

Fig. 1. Restriction patterns obtained with the endonucleases Pacl and Pmel. (a) Lanes: $1, \lambda$ DNA ladder (the lowest band corresponds to the $97 \mathrm{~kb}$ band); 2 , resolution of bands $\mathrm{C}-\mathrm{H}$ of the complete Pmel digestion. (b) Lanes: 1 , complete Pmel digestion; $2, S$. cerevisiae YPH80 marker starting at $225 \mathrm{~kb} ; 3, \lambda$ DNA ladder starting from $48.5 \mathrm{~kb} ; 4$, complete Pacl digestion. (c) Schematic representation of the Pmel and Pacl digestion patterns shown in (b) and band designation.

amounts of chromosome contamination which comigrate with these bands, it was not always possible to use them to identify partial digestion products.

As for band A, a PCR-derived probe was obtained using DNA from this band as template. At least 40 different random 10-mers were used as primers and one yielded a specific amplification product. This amplified band was used as a probe and shown to be completely specific for band $\mathrm{A}$ of the PmeI digestion pattern. When using this material to probe a PacI total digestion, band 7 was unequivocally identified (data not shown). The fact that it was possible to accurately identify one specific band allowed for the precise mapping of bands linked to the tagged fragment through partially digested DNA. It was then possible to identify from one to five partial products depending on the size of the specific fragment being tagged (Fig. 2b).

\section{Circular linkage map of the P.s. phaseolicola chromosome}

DNA from different $\operatorname{Tn} 5$ mutants was subjected to partial restriction and the different products identified by Southern blot hybridization with the Tn5-specific probe. This allowed us to identify the specific partial products for different bands of the PacI or PmeI patterns. To obtain accurate measurements of partially digested DNA from the Tn5 mutants, at least two different PFGE conditions were always used to clearly resolve large and small fragments. Furthermore, in those cases where 
Table 1. Size of fragments obtained after complete digestion of the P.s. phaseolicola chromosome with Pacl and Pmel

Fragment sizes are the means of at least three different experiments.

\begin{tabular}{|c|c|c|c|}
\hline \multicolumn{2}{|c|}{ PacI } & \multicolumn{2}{|c|}{ PmeI } \\
\hline Fragment & Size $(\mathbf{k b} \pm S D)$ & Fragment & Size $(k b \pm S D)$ \\
\hline 1 & $27 \pm 1$ & A & $29 \pm 4$ \\
\hline 2 & $62 \pm 1$ & B & $42 \pm 2$ \\
\hline 3 & $109 \pm 1$ & $\mathrm{C}$ & $141 \pm 4$ \\
\hline 4 & $132 \pm 2$ & $\mathrm{D}$ & $164 \pm 6$ \\
\hline 5 & $152 \pm 2$ & $\mathrm{E}$ & $171 \pm 5$ \\
\hline 6 & $166 \pm 1$ & $\mathrm{~F}$ & $178 \pm 3$ \\
\hline 7 & $262 \pm 2$ & G & $194 \pm 3$ \\
\hline 8 & $276 \pm 2$ & $\mathrm{H}$ & $209 \pm 6$ \\
\hline 9 & $337 \pm 2$ & I & $270 \pm 20$ \\
\hline 10 & $397 \pm 6$ & J & $323 \pm 17$ \\
\hline 11 & $573 \pm 26$ & $\mathrm{~K}$ & $463 \pm 15$ \\
\hline 12 & $702 \pm 19$ & $\mathrm{~L}$ & $488 \pm 13$ \\
\hline 13 & $726 \pm 17$ & M & $655 \pm 14$ \\
\hline 14 & $843 \pm 2$ & $\mathrm{~N}$ & $721 \pm 18$ \\
\hline \multirow[t]{2}{*}{15} & $876 \pm 4$ & $\mathrm{O}$ & $755 \pm 19$ \\
\hline & & $\mathbf{P}$ & $839 \pm 20$ \\
\hline Sum & 5640 & Sum & 5642 \\
\hline \multicolumn{4}{|c|}{ Chromosome size: $5641 \mathrm{~kb}$} \\
\hline
\end{tabular}

more than one $\operatorname{Tn} 5$ strain tagging the same restriction fragment were available, DNA samples from at least two independent mutants were used to confirm hybridization data.

Initially the linkage for the different fragments generated with PacI was obtained using data from the partial digestions and a preliminary circular map was deduced. This preliminary map was confronted with the crosshybridization data for the PacI and PmeI bands and some minor changes were introduced for map areas where previous data had been ambiguous. A final version was obtained using specific partial digestion data for PmeI to confirm specific linkages. The data obtained are summarized in Fig. 3.

\section{Locating rRNA operons, promoter-probe-derived mutants and the argK gene of $P$.s. phaseolicola within the physical map}

A $1.5 \mathrm{~kb}$ DNA fragment corresponding to the Xanthomonas campestris pv. campestris rrs (16S) structural gene was labelled with ${ }^{32} \mathrm{P}$ and used as probe to localize the corresponding gene of P.s. phaseolicola. Hybridization signals were obtained in bands $10,11,13,14$ and $\mathrm{P}, \mathrm{N}, \mathrm{O}, \mathrm{M}$ of the $\mathrm{PacI}$ and $\mathrm{PmeI}$ digestions, respectively, and thus, at least four rrs genes could be unambiguously identified (Fig. 4a). However, the intensity of the signal (a)

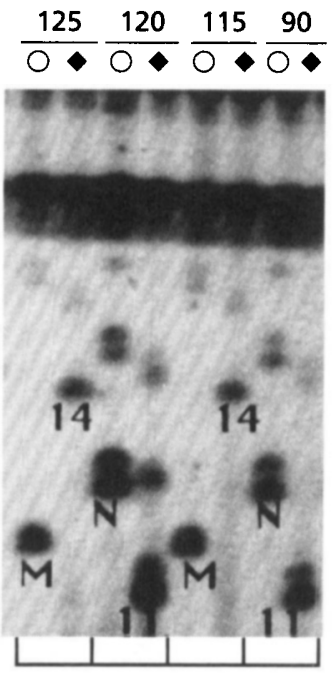

(b)

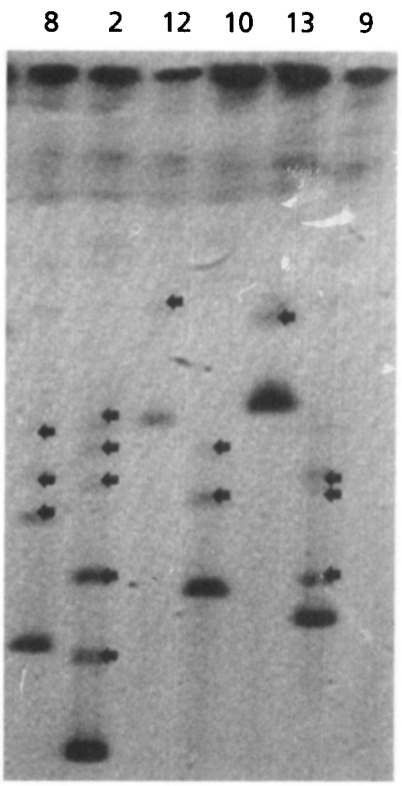

Fig. 2. Identification of bands carrying a Tn5 insertion (tag) and identification of specific partial restriction products. (a) DNA from strains 125, 120, 115 and 90 was restricted with both Pmel $(O)$ and $\mathrm{PaCl}(\bullet)$, the digestion products transferred to a membrane and hybridized to a Tn5 probe. The Tn5 tag in mutants 125 and 115 was located in bands $M$ and 14 of the Pmel and Pacl patterns, respectively. As for mutants 120 and 90, the tag was in bands $\mathrm{N}$ and 11 of the Pmel and Pacl patterns, respectively. Some partial products can be identified. (b) DNA from mutants having tags in Pacl bands 8, 2, 12, 10, 13 and 9. DNA was transferred to a membrane and probed with Tn5 DNA. The arrowheads indicate those partial products that could be identified and sized to provide linkage data. The total digestion product is the stronger lowest band in each lane and corresponds to the tagged band.

corresponding to bands 14 and $\mathrm{M}$ was stronger than for the other bands, suggesting that within the map region spanned by these bands there could be more than one region corresponding to another rrs gene. To determine unambiguously the number of ribosomal genes, I-CeuI, an intron-encoded endonuclease which cleaves specifically within the bacterial $r r$ (23S) genes (Liu et al., 1993), was used to digest total DNA from P.s. phaseolicola.

Five distinct bands were obtained with I-CeuI. When sizing these DNA fragments it was noticeable that under the PFGE conditions used, their sizes were a mean of $8 \%$ different from those calculated previously for similarsized PacI or PmeI fragments. This error was much more evident for the two larger I-CeuI bands when sized against the $H$. wingei markers. However, anomalous mobilities have been reported for the $H$. wingei markers under certain PFGE conditions (Jones et al., 1989). Based on the fact that four of the rrs genes could be clearly assigned to specific PacI and PmeI fragments by hybridization, and using the $8 \%$ error margin, it was possible to calculate accurately the size of the I-CeuI 
Table 2. Localization of Tn5 in the bands generated by restriction with Pacl and Pmel of total DNA from some P.s. phaseolicola mutants

\begin{tabular}{|lcc|}
\hline Strain designation & \multicolumn{2}{c|}{ Tn5 localization } \\
\cline { 2 - 3 } & PacI & PmeI \\
\hline UIC-1 & 6 & H \\
UIC-2 & 9 & G \\
UIC-5 & 13 & O \\
UIC-10 & 15 & K \\
UIC-18 & 10 & P \\
UIC-34 & 8 & I \\
UIC-35 & 6 & P \\
UIC-45 & 5 & L \\
UIC-66 & 12 & P \\
UIC-75 & 12 & L \\
UIC-80 & 3 & O \\
UIC-85 & 2 & H \\
UIC-90 & 11 & N \\
UIC-115 & 14 & M \\
UIC-145 & 15 & J \\
UIC-150 & 13 & F \\
\hline
\end{tabular}

fragments which turned out to be $0.196,0.471,0.912$, 1.492 and $2.616 \mathrm{Mb}$, a total of $5.68 \mathrm{Mb}$ compared to the $5.64 \mathrm{Mb}$ estimated with the PacI and PmeI values (Fig. 4b). The rrs hybridization data together with the I-CeuI results unambiguously revealed the presence of five sets of ribosomal genes located on the chromosome of P.s. phaseolicola as shown in Fig. 5.

To identify genes whose expression is temperaturedependent and which may be linked to phaseolotoxin synthesis, we constructed a promoter-probe derived from Tn5 which carries a promoterless chloramphenicol acetyltransferase (cat) gene, allowing for positive selection of promoters after transposition (R. Marsch-Moreno, G. Hernández-Guzmán \& A. Alvarez-Morales, unpublished). With this element we have mutagenized P.s. phaseolicola, selecting for $\mathrm{Cm}^{\mathrm{R}}$ at $18^{\circ} \mathrm{C}$, and have found several mutants with this response pattern. Also, we have found some mutants in which promoter activity seems to be dependent on the presence of plant extracts. The characteristics of these mutants are summarized in Table 5 and their location, together with that of the $\arg K$ gene are shown in Fig. 5.

\section{DISCUSSION}

A physical map of the P.s. phaseolicola genome has been constructed by ordering the 15 and 16 large restriction fragments generated with the enzymes Pacl and PmeI, respectively. Most of the restriction fragments were tagged with $\operatorname{Tn} 5$ insertions and the map was generated after Southern blot analysis of the fragments obtained by complete and partial restriction digests. PCR-derived probes and bands isolated from agarose gels from fragments which were not tagged were used as probes. The values reported for the chromosome size of four different $P$. aeruginosa strains ranged between $5 \cdot 2$ and $7 \cdot 0 \mathrm{Mb}$ (Römling et al., 1989; Hector \& Johnson, 1990; Schmidt et al., 1996). We have determined the size of the single circular chromosome of P.s. phaseolicola to be $5.64 \mathrm{Mb}$, a value similar to those reported for some $P$. aeruginosa strains, but smaller than the $6.63 \mathrm{Mb}$ chromosome of $P$. fluorescens (Rainey \& Bailey, 1996).

When the different fragments obtained with both PacI and $P m e I$ were linked, a circular map could be readily obtained. The use of an already available collection of Tn 5 insertion mutants proved extremely useful since it allowed us to identify strains where the Tn5 insertion was tagging a specific band. Partial digestion of DNA

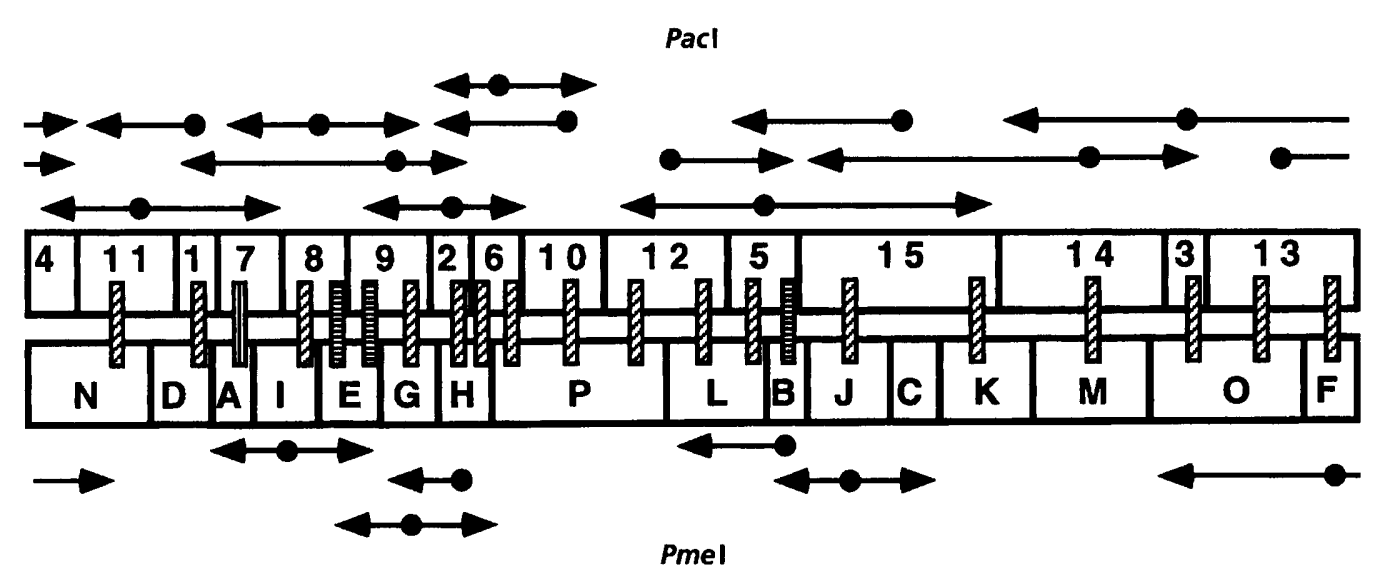

Fig. 3. Fragment linkages through partial restriction and cross-hybridization data. The arrows indicate those fragments linked through partial restriction data; the black dot indicates the Tn5-tagged band used in the analysis. The hatched bars indicate cross-hybridization obtained using different types of probes: vertical hatching, PCR-derived probe from band $A$; horizontal hatching, band $B$ and $E$ used as probes after gel elution; diagonal hatching, Tn5 probe. Fragment sizes are not drawn to scale. 
Table 3. Location and relevant phenotype of promoter-probe-derived mutants and the argK gene of P.s. phaseolicola

\begin{tabular}{|lrcl|}
\hline Allele & \multicolumn{2}{c}{ Location } & \multicolumn{1}{c|}{ Phenotype/selection } \\
\cline { 2 - 3 } & PacI & PmeI & \\
\hline UIM-21 & 13 & $\mathrm{O}$ & $\mathrm{Cm}^{\mathrm{R}}$ at $16^{\circ} \mathrm{C}$ in $\mathrm{KB}$ medium \\
UIM-B & 13 & $\mathrm{O}$ & $\mathrm{Cm}^{\mathrm{R}}$ at $16^{\circ} \mathrm{C}$ in $\mathrm{M} 9$ medium \\
UIM-C & 8 & $\mathrm{I}$ & $\mathrm{Cm}^{\mathrm{R}}$ at $16^{\circ} \mathrm{C}$ in $\mathrm{M} 9$ medium \\
UIM-E & 12 & $\mathrm{~L}$ & $\mathrm{Cm}^{\mathrm{R}}$ at $16^{\circ} \mathrm{C}$ in $\mathrm{M} 9$ medium \\
UIM-F & 6 & $\mathrm{H}$ & $\mathrm{Cm}^{\mathrm{R}}$ at $16^{\circ} \mathrm{C}$ in $\mathrm{M} 9$ medium \\
UIM-E24 & 14 & $\mathrm{M}$ & $\mathrm{Cm}^{\mathrm{R}} / \mathrm{plant}$ extract $/ 28^{\circ} \mathrm{C} / \mathrm{KB}$ medium \\
UIM-E4 & 14 & $\mathrm{M}$ & $\mathrm{Cm}^{\mathrm{R}} / \mathrm{plant}$ extract $/ 28^{\circ} \mathrm{C} / \mathrm{KB}$ medium \\
argK & 8 & $\mathrm{I}$ & Phaseolotoxin-insensitive OCTase \\
\hline
\end{tabular}

(a)

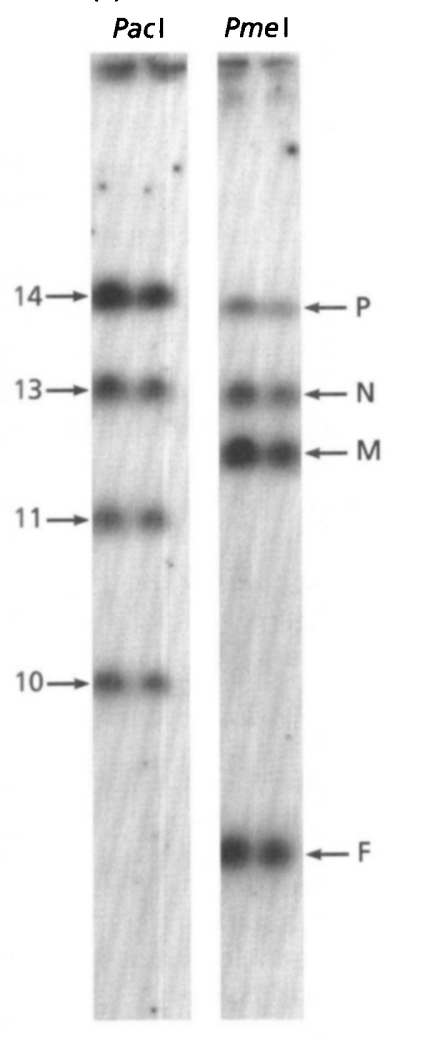

(b)

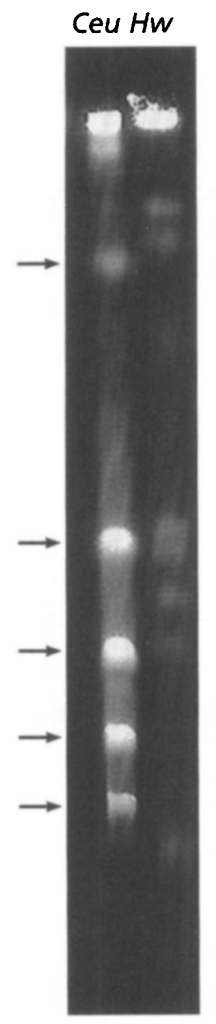

Fig. 4. Determination of number and position of putative rRNA transcriptional units of P.s. phaseolicola. (a) Pacl- and Pmeldigested DNA hybridized with a $1.5 \mathrm{~kb}$ DNA fragment corresponding to the $X$. campestris pv. campestris rrs (16S) structural gene. The bands showing a hybridization signal are labelled for each restriction pattern. Both lanes in each digest correspond to slightly different amounts of the same DNA. (b) Lane Ceu shows the five bands obtained after digestion of chromosomal DNA from P.s. phaseolicola with I-Ceul (arrows). Lane $H w$ corresponds to the $H$. wingei DNA marker.

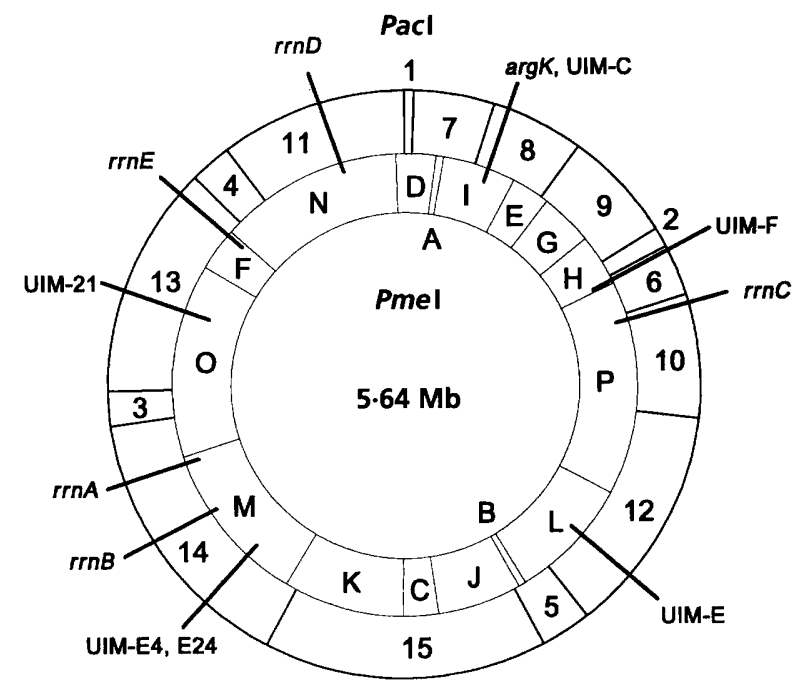

Fig. 5. Physical map of P.s. phaseolicola. The map is drawn to scale. The location of five putative $r r n$ transcriptional units, $\arg K$ and some promoter-probe-derived mutants is indicated.

from these mutants yielded up to five different and readily identifiable partial restriction fragments using a Tn5 probe. This information, together with the data provided by linking PacI and PmeI bands through the Tn 5 tag made the use of two-dimensional PFGE analysis unnecessary.

The analysis of 150 independently obtained $\operatorname{Tn} 5$ mutants did not allow us to identify Tn5 insertions in each of the PacI or PmeI restriction products. Therefore, when it became necessary to generate probes for these fragments, the easiest way to do it was to isolate the particular band from a preparative gel and label it with ${ }^{32} \mathrm{P}$ through random priming. This yielded probes that were very often contaminated with small amounts of comigrating chromosomal DNA but were nevertheless good enough to identify complete digestion products, 
and in some cases, where background due to the contaminant DNA was not high, even partial digestion products could be unambiguously identified. Another way to obtain specific probes is through PCR, which yields completely specific probes, but only if a large collection of random primers is available and only after trying several of these which could prove to be expensive and time-consuming. A similar method based on the use of $\operatorname{Tn} 917$ insertions has been used to assign restriction fragments from different strains of Bacillus subtilis, known to carry an insertion in a genetically defined gene, to a well-developed genetic map, thus obtaining a correlated physical and genetic map (Ventra \& Weiss, 1989).

Since most or all of the genes involved in the synthesis of phaseolotoxin, including $\operatorname{argK}$, seem to be linked (Zhang et al., 1993), it became interesting to map the argK gene and the different alleles already identified through the use of a promoter-probe transposon. As shown in Table 3 and Fig. 5, $\operatorname{argK}$ overlaps fragments 8 and I on the physical map and another mutant, UIM-C, selected for its ability to express $\mathrm{Cm}^{\mathrm{R}}$ at $16^{\circ} \mathrm{C}$, falls within this same segment. Since phaseolotoxin synthesis occurs at $16^{\circ} \mathrm{C}$, it would not be surprising to find that mutant UIM-C is involved in this phenomenon. We also found that some mutants, such as UIM-E24 and UIM-04, could express $\mathrm{Cm}^{\mathrm{R}}$ only in the presence of plant extracts. These mutants would seem good candidates to carry the Tn5 insertion on genes involved in pathogenicity and/or virulence and they map in a completely different position within the physical map, suggesting that not all the genes, operons or regulons involved in the pathogenic process are clustered. The other group of mutants mapped and which also respond to temperature may be linked to the infection process but this remains to be tested.

In $P$. aeruginosa and $P$. fluorescens the rRNA genes are organized as transcriptional units with the $5^{\prime}$-rrs-rrl-rrf3' structure typical of eubacteria (Hartmann et al., 1986; Rainey \& Bailey, 1996). To locate the ribosomal genes of P.s. phaseolicola, two approaches were taken: hybridization with an $r r s$ probe to locate genes encoding $16 \mathrm{~S}$ RNA and restriction with I-CeuI which cleaves within the $r r l$ gene encoding 23S RNA. The data obtained in both cases identified five sites on the chromosome where these genes were located, indicating a close linkage between the $r r s$ and the $r r l$ genes. Therefore, it would seem reasonable to expect that the genes encoding rRNA that have been identified in this work are part of a typical $5^{\prime}-r r s-r r l-r r f-3^{\prime}$ transcriptional unit similar to those identified in $P$. aeruginosa and $P$. fluorescens, and maintained in the closely related $P$. syringae.

Furthermore, it is interesting to note that for $P$. aeruginosa $\mathrm{PAO}$, four $\mathrm{rRNA}$ operons have been identified (Römling et al., 1989; Holloway et al., 1994), whereas for $P$. fluorescens five such structures were found (Rainey \& Bailey, 1996). In the case of P.s. phaseolicola five putative $r r n$ transcriptional units have been unambiguously identified in this study. Their position on the circular chromosome is shown in Fig. 5 (labelled $r r n A-r r n E$ ) where names have been assigned to follow the pattern that most closely resembles that of $P$. fluorescens to demonstrate possible similarities, such as the pair-wise arrangement of the structures, $r r n A-r r n B$ and $r r n D-r r n E$, and the clustering in one half of the chromosome with a separation of less than $1.0 \mathrm{Mb}$, except for $r r n C$ (Rainey \& Bailey, 1996). These similarities may be expected due to the close relatedness of P.s. phaseolicola and P. fluorescens, both being bacteria that interact with plants, as a pathogen and as a saprophyte, respectively. These similarities may therefore suggest that the putative $r r n$ transcriptional units of P.s. phaseolicola may also be atypical of Gramnegative bacteria, being organized as inverted repeats and having a direction of transcription opposite to the direction of DNA replication. Likewise, the origin of replication of the chromosome may be expected to be found between $r r n A$ and $r r n E$ (Rainey \& Bailey, 1996; Brewer, 1988). However, all these speculations remain to be tested and further work is being undertaken in our laboratory to address these issues.

The physical map generated for this bacterium will serve as the framework on which to build a combined physical and genetic map. Work in this laboratory is under way to determine the direction of transcription of the five rRNA operons, to locate the origin of replication of the chromosome and to map genes involved in pathogenicity, toxin production, hyper-sensitive response and avirulence, among others. The information derived from such a map should prove useful in understanding the evolution of this very important group of plant-pathogenic bacteria and in this context it should be interesting to compare some features of the physical/genetic map of P.s. phaseolicola to the other 45 pathovars of the $P$. syringae group and to the closely related $P$. fluorescens.

\section{ACKNOWLEDGEMENTS}

We would like to thank Gustavo Hernández for providing the Tn5 mutants of P.s. phaseolicola; Azucena Mendoza for helping us with the PCR methods, Cristina Garcidueñas-Piña for technical assistance, Gabriela Olmedo, June Simpson and Luis Herrera for their helpful comments and valuable discussions, and Mike Daniels and Jonathan Carter of the Sainsbury Laboratory, Norwich Research Park, UK, for valuable discussions and for kindly providing the rRNA probe from $X$. campestris. This work was partially supported by the Mexican National Council for Science and Technology (CONACYT).

\section{REFERENCES}

Brewer, B. J. (1988). When polymerases collide: replication and the transcriptional organization of the E. coli chromosome. Cell 53, 679-686.

Goss, R. W. (1970). The relation of temperature to common halo blight of beans. Phytopathology 30, 258-264.

Hartmann, R. K., Toschka, H. Y., Ulbrich, N. \& Erdmann, V. A. (1986). Genomic organization of rDNA in Pseudomonas aeruginosa. FEBS Lett 195, 187-193. 
Hatziloukas, E. \& Panopoulos, N. J. (1992). Origin, structure and regulation of $\operatorname{argK}$, encoding the phaseolotoxin-resistant ornithine carbamoyltransferase in Pseudomonas syringae pv. phaseolicola, and functional expression of $\operatorname{argK}$ in transgenic tobacco. J Bacteriol 174, 5895-5909.

Hector, J. S. R. \& Johnson, A. R. (1990). Determination of genome size of Pseudomonas aeruginosa by PFGE: analysis of restriction fragments. Nucleic Acids Res 18, 3171-3174.

Holloway, B. W., Römling, U. \& Tümmler, B. (1994). Genomic mapping of Pseudomonas aeruginosa PAO. Microbiology 140, 2907-2929.

Jones, C. P., Janson, M. \& Nordenskjöld, M. (1989). Separation of yeast chromosomes in the megabase range suitable as size markers for pulsed-field gel electrophoresis. Technique 1, 90-95.

Kauc, L., Mitchell, M. \& Goodgal, S. H. (1989). Size and physical map of the chromosome of Haemophilus influenzae. J Bacteriol 171, 2474-2479.

Lee, J. J. \& Smith, H. O. (1988). Sizing of the Haemophilus influenzae $\mathrm{Rd}$ genome by pulsed-field agarose gel electrophoresis. $J$ Bacteriol 170, 4402-4405.

Lee, J. J., Smith, H. O. \& Redfield, R. J. (1989). Organization of the Haemophilus influenzae Rd genome. J Bacteriol 171, 3016-3024.

Lelliot, R. A. \& Stead, D. E. (1987). Methods for the diagnosis of bacterial diseases of plants. In Methods in Plant Pathology, Vol. 2, pp. 176-177. Edited by T. F. Preece. Oxford: Blackwell Scientific Publications.

Liu, S.-H., Hessel, A. \& Sanderson, K. E. (1993). Genomic mapping with I-CeuI, an intron encoded endonuclease specific for genes for ribosomal RNA, in Salmonella spp., Escherichia coli, and other bacteria. Proc Natl Acad Sci USA 90, 6874-6878.

McClelland, M., Jones, R., Patel, Y. \& Nelson, M. (1987). Restriction endonucleases for pulse field mapping of bacterial genomes. Nucleic Acids Res 15, 5985-6005.

Manna, A. C. \& Das, H. K. (1993). Determination of the size of the Azotobacter vinelandii chromosome. Mol Gen Genet 241, 719-722.

Manna, A. C. \& Das, H. K. (1994). The size of the chromosome of Azotobacter chroococcum. Microbiology 140, 1237-1239.

Mitchell, R. E. (1978). Halo blight of beans: toxin production by several Pseudomonas syringae isolates. Physiol Plant Pathol 13, $37-49$.

Mosqueda, G., Van den Broeck, G., Saucedo, O., Bailey, A.-M., Alvarez-Morales, A. \& Herrera-Estrella, L. (1990). Isolation and characterization of the gene from Pseudomonas syringae pv. phaseolicola encoding the phaseolotoxin-insensitive ornithine carbamoyltransferase. Mol Gen Genet 222, 461-466.

Peet, R. C. \& Panopoulos, N. J. (1987). Ornithine carbamoyl transferase genes and phaseolotoxin immunity in Pseudomonas syringae pv. phaseolicola. EMBO J 6, 3585-3591.

Poddar, S. K. \& McClelland, M. (1992). Non-specific primer and
PCR generated hybridization probes for physically ordering large restriction fragments in complex genome of $S$. aureus. Biochem Biophys Res Comm 185, 1055-1061.

Pyle, L. E., Corcoran, L. N., Cocks, B. G., Bergemann, A. D., Whitley, J. C. \& Finch, L. R. (1988). Pulsed-field electrophoresis indicates larger-than-expected sizes for mycoplasma genomes. Nucleic Acids Res 16, 6015-6025.

Rainey, P. B. \& Bailey, M. J. (1996). Physical and genetic map of the Pseudomonas fluorescens SBW25 chromosome. Mol Microbiol 19, 521-533.

Römling, U., Grothues, D., Bautsch, W. \& Tümmler, B. (1989). A physical genome map of Pseudomonas aeruginosa PAO. EMBO J 8, 4081-4089.

Sambrook, J., Fritsch, E. F. \& Maniatis, T. (1989). Molecular Cloning: a Laboratory Manual, 2nd edn. Cold Spring Harbor, NY: Cold Spring Harbor Laboratory.

Schmidt, K. D., Tümmler, B. \& Römling, U. (1996). Comparative genome mapping of Pseudomonas aeruginosa PAO with $P$. aeruginosa $\mathrm{C}$, which belongs to a major clone in cystic fibrosis and aquatic habitats. J Bacteriol 178, 85-93.

Schwartz, D. C. \& Cantor, C. R. (1984). Separation of yeast chromosome sized DNAs by pulsed field gradient gel electrophoresis. Cell 37, 67-75.

Smith, C. L., Matsumoto, T., Niwa, O., KIco, S., Fan, J., Yanagida, M. \& Cantor C. R. (1987a). An electrophoretic karyotype for Schizosaccharomyces pombe by pulsed field gel electrophoresis. Nucleic Acids Res 15, 4481-4489.

Smith, C. L., Econome, J. G., Schutt, A., KIco, S. \& Cantor C. R. (1987b). A physical map of the Escherichia coli K12 genome. Science 236, 1448-1453.

Smith, C. L., Klco, S. R. \& Cantor, C. R. (1988). Pulse field gel electrophoresis and the technology of large DNA molecules in genome analysis. In Genome Analysis; a Practical Approach, pp. 41-72. Edited by K. Davies. Oxford: IRL Press.

Snell, R. G. \& Wilkins, R. J. (1986). Separation of chromosomal DNA molecules from C. albicans by pulse field gel electrophoresis. Nucleic Acids Res 14, 4401-4405.

Sor, F. (1988). A computer program allows the separation of a wide range of chromosomes sizes by pulse field gel electrophoresis. Nucleic Acids Res 16, 4853-4863.

Ventra, L. \& Weiss, A. S. (1989). Transposon-mediated restriction mapping of the Bacillus subtilis chromosome. Gene 78, 29-36.

Young, J. M., Takikawa, Y., Gardan, L. \& Stead, D. E. (1992). Changing concepts in the taxonomy of plant pathogenic bacteria. Annu Rev Phytopathol 30, 67-105.

Zhang, Y., Rowley, K. B. \& Patil, S. S. (1993). Genetic organization of a cluster of genes involved in the production of phaseolotoxin, a toxin produced by Pseudomonas syringae pv. phaseolicola. J Bacteriol 175, 6451-6458.

Received 11 August 1997; revised 15 September 1997; accepted 8 October 1997. 